\title{
Are Liver Transaminases and Hepatitis C Virus-RNA Viral Loads Reliable Markers for Estimating Liver Fibrosis in Patients Recently Diagnosed with Hepatitis C? Evaluation of the Data of Ninety-five Young and Middle-aged Males in a Genotype-1b Prevalent Country
}

Yeni Hepatit C Tanılı Hastalarda Karaciğer Transaminazları ve Hepatit C VirüsRNA Viral Yükleri Karaciğer Fibrozunu Öngörmede Güvenilir Belirleyiciler midir? Genotip-1b Baskın Bir Ülkedeki Doksan-beș Genç ve Orta Yașlı Erkeğe Ait Verilerin Değerlendirilmesi

\author{
(1) Ercan Yenilmez, (1) Rıza Aytaç Çetinkaya
}

Istanbul Sultan Abdülhamid Han Training and Research Hospital, Clinic of Infectious Diseases and Clinical Microbiology, Istanbul, Turkey

\section{ABSTRACT}

Objectives: Although liver biopsy is an invasive test, it is still considered as the gold standard method for determining the severity of liver diseases.

Materials and Methods: A total of 95 young and middle-aged male patients were enrolled in this retrospective study. ISHAK scoring-system was used for pathological assessment. The relationships between alanine aminotransferase (ALT), aspartate aminotransferase (AST), AST/ALT ratio, hepatitis C virus (HCV)RNA and histological activity index (HAl) scores in the prediction of fibrosis stages were evaluated.

Results: To predict a $F \geq 3$, age $>35$ [odds ratio (OR): 3.56 ; $95 \%$ confidence interval (Cl): 1.24-10.24; $\mathrm{p}=0.021)]$ was considered a significant risk factor. For a $\mathrm{F} \geq 2, \mathrm{ALT}$ and $\mathrm{AST}$ values over $40 \mathrm{IU} / \mathrm{mL}$ were found to be significant risk factors (OR: $2.97 ; 95 \% \mathrm{Cl}: 1.09$ 8.06; $p=0.03$, OR: 2.88; 95\% Cl: 1.17- 7.09; $p=0.020$, respectively). All indirect fibrosis parameters except $\mathrm{HAl}$ showed low to moderate diagnostic accuracy in the prediction of both $F \geq 2$ and $F \geq 3$ (AUC 0.50 to 0.68 ). According to the receiver operation characteristic $(\mathrm{ROC})$ analysis results, the optimal cut-off values for predicting $\mathrm{F} \geq 3$ for ALT, AST, AST/ALT ratio, Log10 HCV-RNA and HAI were $94 \mathrm{U} / \mathrm{L}$,
ÖZ

Amaç: Karaciğer biyopsisi invaziv bir yöntem olmakla birlikte hala karaciğer hastalıklarının ciddiyetini belirlemek için altın standart yöntem olarak kabul edilir.

Gereç ve Yöntemler: Bu retrospektif çalışmaya toplam 95 genç ve orta yaşılı erkek hasta dahil edildi. Patolojik değerlendirme için ISHAK skorlama sistemi kullanıldı. Fibrozisin evrelerinin öngörülmesinde alanin aminotransferaz (ALT), aspartat aminotransferaz (AST), AST/ ALT oranı ile HCV-RNA ve histolojik aktivite indeksi (HAl) skorları arasındaki ilișkiler araştıııldı.

Bulgular: F3'ü öngörmede, > 35 yaşın [olasılık oranı (OR): 3.56; \%95 güven aralığı (Cl): 1.24-10.24; $p=0$,021] önemli bir risk faktörü olduğu gösterildi. $\mathrm{F} \geq 2$ için, $40 \mathrm{IU} / \mathrm{mL}$ 'nin üzerindeki $\mathrm{ALT}$ ve AST değerlerinin önemli risk faktörleri olduğu ortaya kondu (sırasıyla OR: 2,97; \%95 Cl: 1,09-8,06; $p=0,03$ ve OR: 2,88; \%95 Cl: 1,17-7,09; $p=0,020$ ). HAl dışındaki tüm indirek fibroz göstergeleri, hem $F \geq 2$ hem de $F \geq 3$ 'ü (AUC 0,50 ila 0,68) öngörmede düşük/orta dereceli tanısal doğruluk gösterdi. Alıcı işletim karakteristiği (ROC) analiz sonuçlarına göre, ALT, AST, AST/ALT oranı, Log10 HCV-RNA ve HAl için F $\geq 3$ 'ü öngörmedeki optimum kesme değerleri sırasıyla $94 \mathrm{U} / \mathrm{L}, 55 \mathrm{U} / \mathrm{L}, 0,78,6,88$ ve 6 idi.

Yenilmez E, Çetinkaya RA. AreAre Liver Transaminases and Hepatitis C Virus-RNA Viral Loads Reliable Markers for Estimating Liver Fibrosis in Patients Recently Diagnosed with Hepatitis C? Evaluation of the Data of Ninety-five Young and Middle-aged Males in a Genotype-1b Prevalent Country. Viral Hepat J. 2019;25:67-74. 
$55 \mathrm{U} / \mathrm{L}, 0.78,6.88$ and 6, respectively. However, only ALT, AST and $\mathrm{HAl}$ had statistically significant results in the ROC analysis $(p<0.05)$. Conclusion: Age, AST, ALT and HAl were considered to be better predictors than AST/ALT ratio and HCV-RNA for estimating liver fibrosis in patients infected with HCV. However, our findings are not sufficient to recommend follow-up of chronic HCV patients based on these parameters only.

Keywords: ALT, AST, Chronic HCV, fibrosis, HCV-RNA necroinflammation
Bununla birlikte, ROC analizindeki sonuçlar sadece ALT, AST ve HAl için istatistiksel olarak anlamlı sonuçlara sahipti $(p<0,05)$.

Sonuç: Yaş, AST, ALT ve HAl'nin karaciğerdeki fibrozu öngörmede AST/ALT oranı ve HCV-RNA'dan daha parametreler olduğu düşünülmektedir. Ancak, bulgularımız kronik HCV'li hastaları sadece bu parametrelere dayanarak takibi önermek için yeterli değildir. Anahtar Kelimeler: ALT, AST, Kronik HCV, Fibroz, HCV-RNA nekroinflamasyon

\section{Introduction}

Hepatitis $\mathrm{C}$ virus (HCV) infection remains an important cause of liver cirrhosis and hepatocellular carcinoma (HCC) despite improvement in treatment modalities. It is estimated that there are 185 million people infected with HCV worldwide, 71 million of whom are chronically infected, while about 3-4 million people are considered to be infected annually $(1,2)$. The prevalence of $\mathrm{HCV}$ infection differs between $2 \%$ and $3.8 \%$ in Asian countries, and it is the highest with $15 \%$ in Egypt (1). With an approximately $1 \%$ infection rate, Turkey is a low endemic country for $\mathrm{HCV}$, and genotype- $1 \mathrm{~b}$ is reported to be predominant with a $91.1 \%$ rate (3). Iran, Israel and Cyprus are other genotype-1 prevalent countries in the Middle-East, besides Turkey (4).

In our hospital, we have one of the largest liver histopathology results among young patients with chronic hepatitis $\mathrm{C}(\mathrm{CHC})$ infection from genotype-1b prevalent countries in literature. Most of the patients underwent liver biopsy because of military regulations in Turkey. They were mostly newly diagnosed naive, young patients and all had no coinfection or other comorbidities.

Determination of the severity of liver disease is one of the most important stages in the management of patients. However, both patients and clinicians are reluctant to perform liver biopsy due to the invasiveness of the procedure. The aim of present study is to reveal the importance of liver transaminases and HCV-RNA levels to predict the severity of liver diseases.

\section{Materials and Methods}

This retrospective study was conducted in a tertiary training and research hospital. The data were gathered and analyzed retrospectively through the patient data management system, liver biopsy and treatment reports. The Clinical Research Ethics Committee of Haydarpaşa Numune Training and Research Hospital on May 22th 2017 (approval number: HNEAH-KAEK 2017/KK/71) and informed consent was obtained from the patients.

\section{Population}

A total of 95 young/middle-aged and male patients, who were all anti-HCV and HCV-RNA positive with a duration of at least six months, enrolled in the study. All of the patients were followed up between January 2008 and January 2017.

Since we work in a military hospital, the vast majority of our cases were new HCV patients diagnosed during the screening process before military service, while the rest were ordinary patients who were candidates for hepatitis $\mathrm{C}$ treatment. Turkey has a mandatory military service, and $\mathrm{CHC}$ patients with findings of $\mathrm{CH}$ in the liver histopathology have the right to be exempted from military service. Furthermore, liver biopsy and histopathologic results were still mandatory until January 2019, for prescribing $\mathrm{HCV}$ treatments according to reimbursement regulations of Turkish Ministry of Health. Moreover, treatment options differ according to HCV-genotype and the level of histopathological findings in the liver. Hence, liver biopsies are performed according to health regulations of the Turkish Armed Forces and of the Turkish Ministry of Health, with the consent of patients with HCV.

\section{Follow-up}

The study data was gathered retrospectively, however the routine follow-up procedure for patients with $\mathrm{HCV}$ is as described below. At the first visit, we checked for patients with a history of $\mathrm{HCV}$ infection, who were referred to our hospital from the recruitment offices or other hospitals, for anti-HCV, HCV-RNA, hepatitis B surface antigen, anti-Human Immunodeficiency Virus (HIV), complete blood count, liver transaminases, albumin, total protein, lipid profile, prothrombin time, alpha-fetoprotein, liver ultrasonography and some other additional tests if necessary. If the patient had anti-HCV and HCV-RNA positivity, we followed up the patient for a period of at least six months. At the end of the follow-up period, we performed the same tests and performed liver biopsies on those who still demonstrated positive HCV-RNA results.

\section{Exclusion Criteria}

Female patients, children and patients over 45 years old, patients who had a history of HCV treatment with interferon-based or directly acting antiviral therapies, who had symptoms of cirrhosis or who were co-infected with other hepatitis viruses or HIV, or who had other chronic liver diseases or history of drug use, were excluded from the study.

\section{Liver Biopsy and Histopathology}

Patients underwent liver biopsy using 16G biopsy needles by the Menghini's aspiration method or subcostal real-time ultrasound-guided liver biopsy by Trucut-style. An adequate biopsy was required to be a minimum of $1.5 \mathrm{~cm}$-long. Histopathologic assessment of liver biopsies was performed according to the Ishak's (5) scoring system for histological grading and staging for $\mathrm{CH}$. Parameters in the study are evaluated in terms of the prediction of fibrosis scores higher than $2(F \geq 2)$ and $3(F \geq 3)$.

\section{Laboratory Tests}

HCV-RNA viral load quantifications were performed by the Roche $^{\circledR}$ COBAS ${ }^{\circledR}$ AmpliPrep/COBAS ${ }^{\circledR}$ Taqman $^{\circledR}$ HCV Quantitative 
Test v2.0 with the lowest detection limit of $15 \mathrm{IU} / \mathrm{mL}$, and the limit of quantification between 15 and $1 \times 108 \mathrm{IU} / \mathrm{mL}$. Anti-HCV tests were performed using chemiluminescence microparticle immunoassay (Abbot ${ }^{\circledR}$, Architect System; Germany). Serum biochemistry tests for alanine aminotransferase (ALT) and aspartate aminotransferase (AST) were measured using biochemical instruments with the upper limit of the normal (ULN) ALT level as $40 \mathrm{U} / \mathrm{L}$.

\section{Statistical Analysis}

Statistical analyses were performed using e-picos calculator (www.e-picos.com). Baseline characteristics were presented as means and standard deviations for continuous variables, and as frequencies and percentages for categorical variables. Comparisons of continuous variables were performed by the independentsamples Student's t-test and Mann-Whitney $U$ test according to those distributions. Categorical variables were compared using the chi-squared test and Fisher's exact test. The receiver operation characteristic (ROC) analysis was used to determine optimal cut-off levels of serum ALT, AST, AST/ALT, Log10 HCV-RNA and histological activity indexes (HAl) scores for the study population. Diagnostic performance was analyzed by Medcalc version 18.9 (free trial application). G*Power 3.1.9.2 was used for performing the post-hoc power analysis. The study had a 90 percent power to detect a minimum of 20 percent difference for significant liver histology among patients categorized according to their serum HCV-RNA, ALT and AST levels.

\section{Results}

A total of 95 naive, male and young/middle aged patients with chronic HCV infection were included in the study. HCV genotype was confirmed in 36 (37.9\%) of the patients; and 28 (93.3\%) of them were genotype-1b. Other genotypes were genotype 1a $(n=2,2.1 \%)$, genotype $2(n=2,2.1 \%)$, genotype $3(n=3,3.15 \%)$ and genotype $4(n=1,1.05 \%)$. Age of the patients varied between 20 and 45, 75.8\% of whom were younger than 35 years-old, while the mean age was 27.9 \pm 8.25 . The mean ALT, AST, AST/ALT ratio, Log10 HCV-RNA level, histological activity index (HAl) and fibrosis scores of all patients were $83.79 \pm 61 \mathrm{U} / \mathrm{L}, 48.01 \pm 25.62$ $\mathrm{U} / \mathrm{L}, \quad 0.67 \pm 0.26, \quad 6.09 \pm 1.11 \mathrm{JU} / \mathrm{mL}, \quad 5.59 \pm 1.82$ and $1.89 \pm 0.88$, respectively. The other main characteristics of the patients are revealed in Table 1. The mean age, ALT, AST, AST/ALT ratio, Log10 HCV-RNA and HAl scores according to fibrosis scores are also presented in Table 2 . There were 21 patients with ALT levels $\leq 40$ $\mathrm{U} / \mathrm{L}$, and these were divided into two groups as patients with ALT levels $\leq 30 \mathrm{U} / \mathrm{L}$ and patients with ALT levels between 31-40 U/L. Mean age, $\mathrm{HAl}$ and fibrosis scores were $23.66 \pm 6.77,4.27 \pm 1.85$ and $1.5 \pm 0.80$ in patients with ALT levels $\leq 30 \mathrm{U} / \mathrm{L}$, respectively. In patients with ALT levels between 31-40 U/L, mean age, HAl and fibrosis scores were also found to be $30.77 \pm 9.61,5.55 \pm 1.94$ and $1.44 \pm 0.88$, respectively.

$\mathrm{HAl}$ of all patients varied between 2 and 10, while the HAl scores of 4, 5, 6 were found to be the most frequent stages of

\begin{tabular}{|l|l|l|l|l|l|}
\hline Table 1. Baseline characteristics of patients in the study & Mean & Median & Minimum & Maximum & Standard deviation \\
\hline Total $(\mathbf{n = 9 5 )}$ & 27.9 & 23 & 20 & 45 & \pm 8.25 \\
\hline Age & 83.79 & 72 & 13 & 333 & \pm 61 \\
\hline ALT & 48.01 & 40 & 13 & 137 & \pm 25.62 \\
\hline AST & 0.67 & 0.61 & 0.29 & 1.61 & \pm 0.26 \\
\hline AST/ALT & 6.09 & 6.25 & 2.76 & 10 & \pm 1.11 \\
\hline Log10 HCV-RNA & 5.59 & 5 & 2 & 5 & \pm 1.82 \\
\hline HAI & 1.89 & 2 & 0 & 5 & \pm 0.88 \\
\hline Fibrosis & Aspartate aminotransferase, HCV: Hepatitis C virus, HAl: Histological activity index & \\
\hline ALT: Alanine aminotransferase, AST: Asp &
\end{tabular}

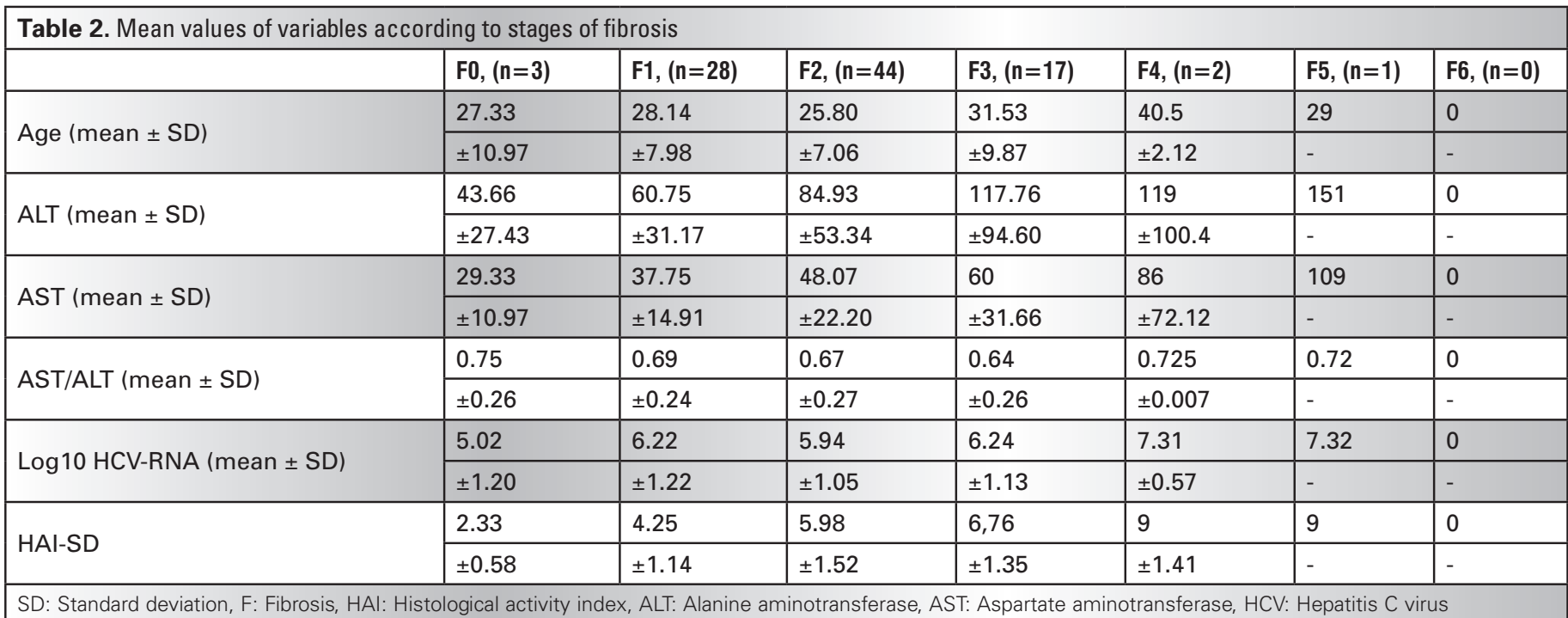


fibrosis ( $n=17,18 \% ; n=22,23 \% ; n=20,21 \%$, respectively). Fibrosis scores of patients which varied between 0 and $5 ; \mathrm{F} 1$ ( $n=28,30 \%$ ), F2 ( $n=44,46 \%)$ and F3 ( $n=17,18 \%)$ were reported as the most frequent stages of fibrosis. The distribution of patients according to $\mathrm{HAl}$ and fibrosis scores is presented in Figure 1A and 1B.

Risk estimation analysis demonstrated that, ALT $>40 \mathrm{IU} / \mathrm{mL}$ [odds ratio (OR): 2.97; confidence interval (Cl) \%95: 1.09-8.06; $\mathrm{p}=0.037 \mathrm{l}$ and $\mathrm{AST}>40 \mathrm{IU} / \mathrm{mL}$ (OR: 2.88; $\mathrm{Cl} \% 95:$ 1.17-7.09; $\mathrm{p}=0.020$ ) were the significant risk factors for $\mathrm{F} \geq 2$, while age $>35$ was the only significant risk factor (OR: 3.56; Cl \%95: 1.24-10.24; $\mathrm{p}=0.021$ ) for $\mathrm{F} \geq 3$. For other parameters, the ORs were not found to be significant (Table 3).

Cut-off values with the optimum sensitivity and specificity for the prediction of $F \geq 2$ and $F \geq 3$ were determined based on the ROC curve analysis. ROC curves and the diagnostic accuracy results are shown on Figure 2, and 3, and in Table 4,5. The area under the Receiver-Operator-Characteristic curves (AUCs) for ALT, AST, AST/ ALT ratio, HCV-RNA and HAl score for the prediction of $F \geq 2$ were $0.65,0.68,0.56,0.50$ and 0.86 , respectively (Table 4). For $F \geq 3$, AUCs for ALT, AST, AST/ALT ratio, HCV-RNA and HAl score were reported as $0.65,0.68,0.53,0.62$ and 0.80 , respectively (Table 5).

The optimum values in the ROC analysis for ALT, AST and HAl were found to be significant $(p<0.05)$, while results of Log10 HCV-RNA and AST/ALT ratio were not ( $p>0.05)$. The optimum ALT level to predict $F \geq 2$ was $104 \mathrm{U} / \mathrm{L}$, while it was $94 \mathrm{U} / \mathrm{L}$ for $\mathrm{F} \geq 3$.
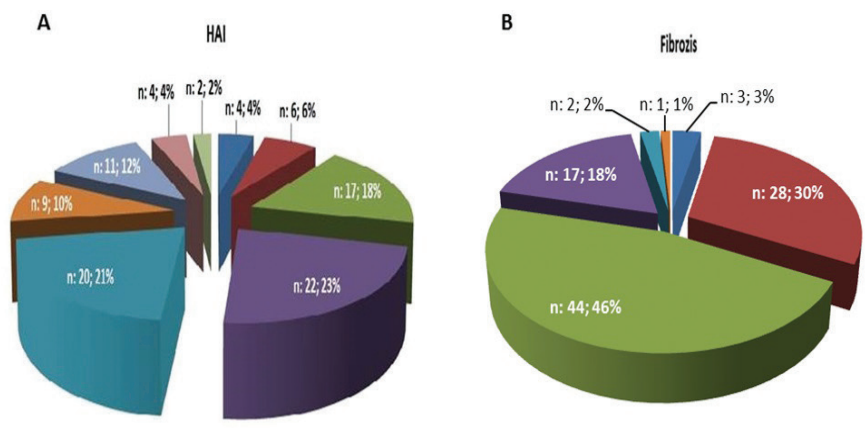

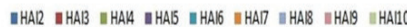

$\triangle F 0 \triangle F 1 \backsim F 2 \square F 3 \backsim F 4 \square F 5$

Figure 1. Distribution of the patients in the study according to fibrosis stages and histologic activity index scores. Graphs according to A) Fibrosis stages, B) necroinflammatory grade (histologic activity index score)
The optimum AST levels for $F \geq 2$ and $F \geq 3$ were 39 and $55 \mathrm{U} / \mathrm{L}$, respectively. The optimum HAl score to predict $F \geq 2$ was reported as 5 , while it was 6 for $F \geq 3$ fibrosis (Table 4,5).

\section{Discussion}

Severity of hepatic fibrosis is the main indicator of end stage liver diseases (ESLD), HCC and liver related death. Bruden DJT revealed that $1.7 \%$ of $\mathrm{HCV}$ patients with mild fibrosis developed ESLD during a five years follow-up period. On the other hand, the rate of developing ESLD was $7.9 \%, 16.4 \%$ and $49 \%$ among the patients with moderate, severe fibrosis and cirrhosis, respectively (6). He also concluded that treatment in patients with mild fibrosis could be deferred for up to five years, and that early treatment is crucial for patients with other than mild fibrosis. Despite recent efforts to develop alternative non-invasive imaging methods, indirect scoring systems or biomarkers, liver biopsy is still considered as the gold standard method to assess necro-inflammation and fibrosis of liver and also to exclude other concomitant liver diseases (7-9). Additionally, a histopathological result of a liver biopsy was required until January 2019 according to the reimbursement arrangements
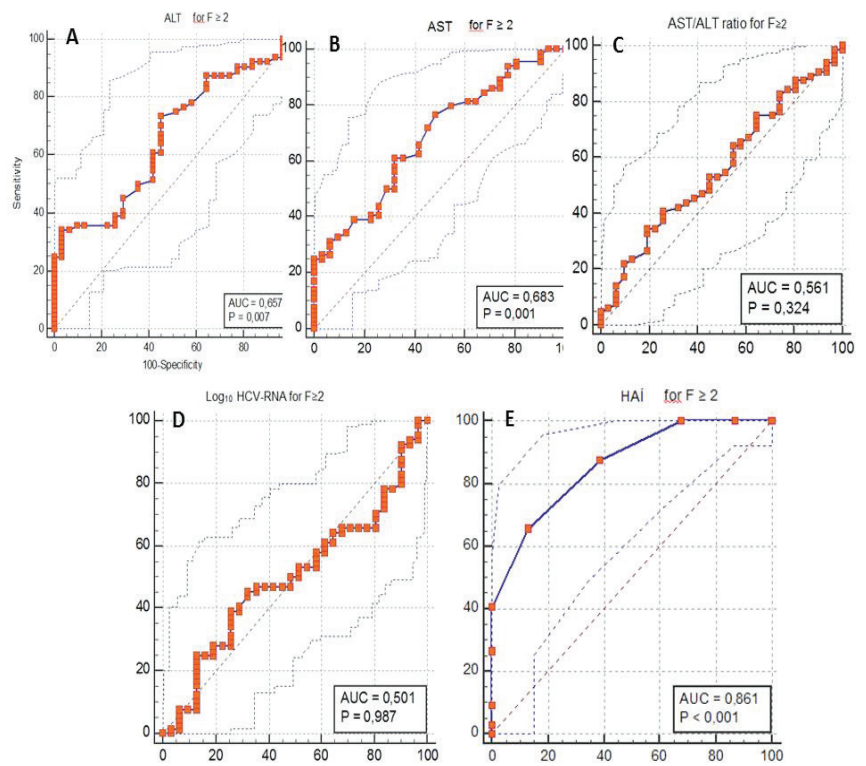

Figure 2. Area under the receiver operating characteristic curves for predicting $\geq 2$ fibrosis stage $(F \geq 2)$. A) Area under the receiver operating characteristic curves (AUC) for alanine aminotransferase (ALT) B) AUC for aspartate aminotransferase (AST). C) AUC for AST/ALT ratio. D) AUC for Log10 hepatitis C virus-RNA E) AUC for histologic activity index score

Table 3. Risk estimation for $\mathrm{F} \geq 2$ and $\mathrm{F} \geq 3$ fibrosis

\begin{tabular}{|c|c|c|c|c|}
\hline \multirow{2}{*}{ Cut-off levels } & \multicolumn{2}{|l|}{$F \geq 2$} & \multicolumn{2}{|l|}{$F \geq 3$} \\
\hline & OR (Cl \%95) & $p$ & OR (Cl \%95) & p \\
\hline Age for $>35$ & $1.14(0.41-3.14)$ & 0.796 & $3.56(1.24-10.24)$ & 0.021 \\
\hline ALT for $>40(\mathrm{U} / \mathrm{L})$ & $2.97(1.09-8.06)$ & 0.037 & 3.65 (0.64-14.39) & 0.225 \\
\hline AST for $>40(\mathrm{U} / \mathrm{L})$ & 2.88 (1.17-7.09 & 0.020 & $2.24(0.80-6.24)$ & 0.118 \\
\hline
\end{tabular}

F: Fibrosis; ALT: Alanine aminotransferase, AST: Aspartate aminotransferase, OR: Odds ratio, Cl: Confidence interval, HCV: Hepatitis C virus

*Prati criteria; $30 \mathrm{U} / \mathrm{L}$ for male, $19 \mathrm{U} / \mathrm{L}$ for female for ULN (upper limit of normal) of ALT 
Table 4. Diagnostic accuracy estimates $(95 \% \mathrm{CI})$ of alanine aminotransferase, aspartate aminotransferase, aspartate aminotransferase/alanine aminotransferase ratio, Hepatitis $\mathrm{C}$ virus-RNA and histological activity index in theprediction of $\mathrm{F} \geq 2$ fibrosis

\begin{tabular}{|c|c|c|c|c|c|}
\hline & ALT (U/L) & AST (U/L) & AST/ALT & Log10 HCV-RNA & HAI \\
\hline Cut-off value & 104 & 39 & 0.5 & 6.78 & 5 \\
\hline AUC & 0.65 & 0.68 & 0.56 & 0.50 & 0.86 \\
\hline $\mathrm{p}$ & 0.007 & 0.001 & 0.324 & 0.987 & 0.001 \\
\hline Sensitivity, & 34.38 & 60.94 & 34.38 & 65.62 & 65.62 \\
\hline $95 \% \mathrm{Cl}$ & 83.3-99.9 & $48.6-83.3$ & $62.5-92.5$ & 7.5-37.5 & $70.2-96.4$ \\
\hline $\mathrm{LR}+$ & 10.66 & 1.89 & 1.78 & 0.81 & 5.09 \\
\hline $95 \% \mathrm{Cl}$ & $1.5-75.5$ & $1.1-3.3$ & 0.8-3.9 & 0.6-1.0 & $2.0-12.9$ \\
\hline LR- & 0.68 & 0.58 & 0.81 & 1.78 & 0.39 \\
\hline NPV & 41.7 & 45.7 & 37.3 & 19.35 & 55.1 \\
\hline $95 \% \mathrm{Cl}$ & $37.2-46.3$ & $36.2-55.4$ & $31.7-43.3$ & 7.5-37.5 & $46.0-63.9$ \\
\hline
\end{tabular}

Table 5. Diagnostic accuracy estimates $(95 \% \mathrm{Cl})$ of alanine aminotransferase, aspartate aminotransferase, alanine aminotransferase/aspartate aminotransferase ratio, Hepatitis $\mathrm{C}$ virus-RNA and Histological activity index in the prediction of $\mathrm{F} \geq 3$ fibrosis

\begin{tabular}{|c|c|c|c|c|c|}
\hline & ALT (U/L) & AST (U/L) & AST/ALT & Log10 HCV-RNA & HAI \\
\hline Cut-off value, & 94 & 55 & 0.78 & 6.88 & 6 \\
\hline AUC & 0.65 & 0.68 & 0.53 & 0.62 & 0.80 \\
\hline Sensitivity & 50 & 50 & 90 & 45 & 65 \\
\hline $95 \% \mathrm{Cl}$ & $27.2-72.8$ & $27.2-72.8$ & $68.3-98.8$ & $23.1-68.5$ & $40.8-84.6$ \\
\hline LR+ & 2.34 & 2.68 & 1.23 & 2.60 & 3.75 \\
\hline $95 \% \mathrm{Cl}$ & $1.3-4.3$ & $1.4-5.1$ & $1.0-1.5$ & $1.3-5.2$ & $2.1-6.8$ \\
\hline LR- & 0.64 & 0.61 & 0.38 & 0.67 & 0.42 \\
\hline $95 \% \mathrm{Cl}$ & $0.4-1.0$ & $0.4-1.0$ & $0.10-1.5$ & $0.4-1.0$ & $0.2-0.8$ \\
\hline $95 \% \mathrm{Cl}$ & $78.9-90.3$ & $79.5-90.5$ & $71.8-97.5$ & $78.9-89.5$ & $82.9-94.2$ \\
\hline
\end{tabular}

of HCV treatments in Turkey. Efforts on finding indirect indicators and the development of non-invasive scoring systems for the severity of liver diseases are increasingly pursued, and these remain one of the main issues in hepatology. Our goal was to reveal whether or not primary virological and biochemical markers could estimate the stage of fibrosis in the liver; at least, it was to reveal the importance of virological and biochemical markers on determining who needs liver biopsy.

In literature, the male sex and older age is concluded as risk factors for the progression of fibrosis. It is slower in younger ages, and the cumulative probability of cirrhosis is higher in patients older than 45 years (10). Furthermore, our study is based on a naive, male and relatively young population younger than 45 years-old; these baseline characteristics of the study may promote the importance 

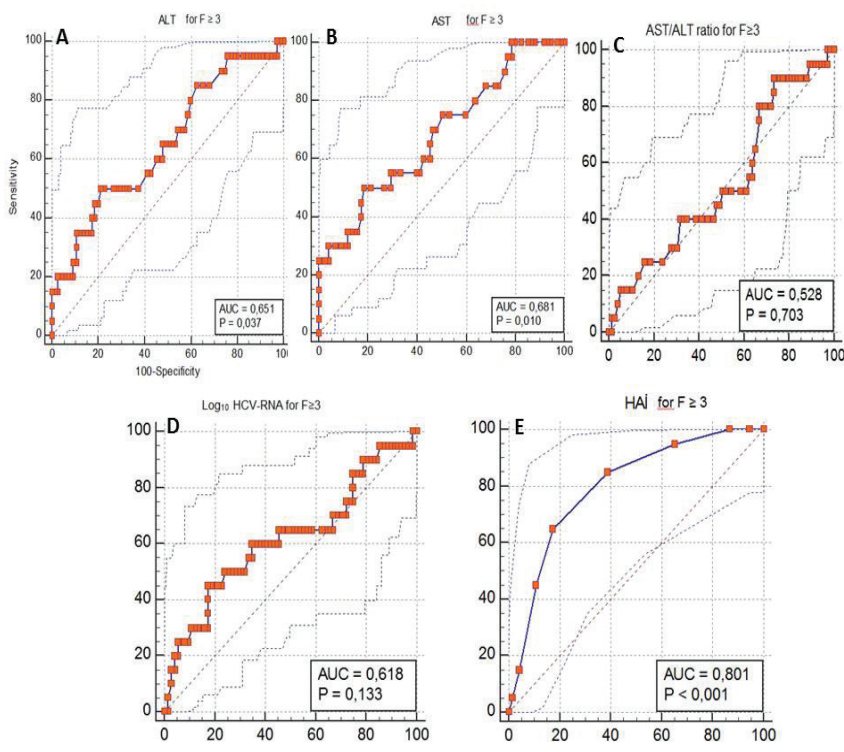

Figure 3. Area under the receiver operating characteristic curves $(A \cup C)$ for predicting $\geq 3$ fibrosis stage $(F \geq 3)$. A) Area under the receiver operating characteristic curves (AUC) for alanine aminotransferase (ALT) B) AUC for aspartate aminotransferase (AST). C) AUC for AST/ ALT ratio. D) AUC for Log-10 Hepatitis C Virus-RNA E) AUC for histologic activity index score

of the results. Because male sex is considered as population with higher risk, and our study population consisted of one of the youngest population in literature. On the other hand, these characteristics of our study could be considered as limitations of the study, and more attention should be paid to adapting study results to the general population.

Age is one of the predictive factors for the severity of hepatic diseases. We revealed that 35 years could be a suitable cut-off age to determine $\mathrm{F} \geq 3$ fibrosis, although our study did not include large number of patients with older age; the mean age raised over 30 years-old in cases with $F \geq 3$. Furthermore, the risk of $F \geq 3$ fibrosis significantly increased over 35 years-old; it was found to be 3.56 times higher in this group. Sanai et al. (11) revealed that age correlated with both fibrosis and necro-inflammation and that age was the only predictor for the severity of necro-inflammation and fibrosis in $\mathrm{CHC}$ patients with normal ALT levels. However, age showed no correlation with both of fibrosis and necro-inflammation in patients with elevated ALT levels according to results in the study.

Transaminases are the main predictive factors of liver inflammation and fibrosis in literature. It is reported that higher ALT is associated with faster hepatic disease progression (12). ALT and AST levels in our study increased in parallel with increase in fibrosis scores. F $\geq 3$ fibrosis is likely to occur over three times more in patients with elevated ALT levels in risk estimation analysis. Both ALT and AST showed moderate diagnostic accuracy with AUC values 0.65 and 0.68 , respectively. The specificity rates were also found to be considerably higher than the sensitivity rates for both $F \geq 2$ and $F \geq 3$ fibrosis. Similarly to our results, Shahid et al. (13) showed that AST and ALT significantly correlated with the stages of fibrosis. However, there are some studies in literature which demonstrates that AST was better than ALT as a marker of the progression of liver damage, or that both transaminases showed no correlation with fibrosis $(11,14,15,16,17,18)$.

In recent years, there has been an increasing trend to lower the ULN to $30 \mathrm{U} / \mathrm{L}$ for ALT for males, which was first revealed by Prati et al. $(19,20,21,22)$. Also in literature, ALT between 25 and $40 \mathrm{U} / \mathrm{L}$ is considered as high normal level in which histopathological changes is thought to be more likely to occur in Hepatitis B (23). In our study, although age and HAl scores were higher in patients with ALT between 31 and $40 \mathrm{U} / \mathrm{L}$, mean fibrosis scores in this patients were not higher than in patients with ALT levels $\leq 30 \mathrm{U} / \mathrm{L}$. Our results did not support the recent literature knowledge; however, the number of patients in our study may be insufficient to comment on this issue.

AST/ALT ratio is one of the important indicators of the stages of fibrosis in literature. In our study, there was no increase in AST/ALT ratio according to the stages of fibrosis, and it had poor diagnostic performance for both $F \geq 2$ and $F \geq 3$ fibrosis. The study results of El-Sayed $R$ et al. (24) were almost the same as ours; they revealed that both AST and the AST/ALT ratio showed a weak correlation with significant fibrosis, and the AUC predicting significant fibrosis was 0.76, which was non-significant. Likewise, Mir IA concluded that the AST/ALT ratio is a non-sensitive marker for liver fibrosis (25). Considering $\geq 1$ ratio, AST/ALT ratio may be useful to determine cirrhosis in $\mathrm{HCV}(26,27)$. Of our patients, only 11 had a ratio of $\geq 1$ AST/ALT, and only two of them had $F \geq 3$ fibrosis. We concluded that the AST/ALT ratio has no value in differentiating the severity of liver disease in patients without cirrhosis.

As another indicator of liver fibrosis in literature, HCV-RNA levels did not differ in five different stages of fibrosis. HCV-RNA levels also showed no significance on risk estimation for both $\mathrm{F} \geq 2$ and $\mathrm{F} \geq 3$ fibrosis considering a HCV-RNA cut-off level of 5 Log10 IU/mL. The diagnostic accuracy of HCV-RNA level was also found to be poor when compared to our results. Although it was correlated with HAl score in the study of Zechini B et al. (18), HCV-RNA was not correlated with fibrosis score. Also similarly to our study results, Gupta et al. (15) revealed that HCV-RNA showed no correlation with both $\mathrm{HAl}$ and fibrosis. In summary, we believe that HCV-RNA should not be considered as a good indicator of liver fibrosis.

HAl scores showed an increase parallel with the increase in fibrosis scores. The HAl score of 5 for $F \geq 2$ and HAl score of 6 for $\mathrm{F} \geq 3$ fibrosis were also found to be statistically significant cut-off values in the ROC analysis. Although HAI may be considered as a good predictive factor of hepatic fibrosis in hepatitis $\mathrm{C}$ infection, it has no value in clinical use. Since, $\mathrm{HAl}$, like fibrosis, requires an invasive procedure and both of them are the results of liver biopsy.

Diagnostic accuracy results of the parameters, except for $\mathrm{HAl}$, in the prediction of $\mathrm{F} \geq 3$ fibrosis in our study were poorer than results obtained from the largest study in literature about the diagnostic accuracy of biomarkers (6). In this study, the authors concluded that liver biopsy could still be performed to diagnose stages of fibrosis in patients without cirrhosis. In another study with one of the largest series, AUC for FIB-4 in discriminating F3-4 from F0-2 was 0.83 for HCV (28). In a review study, combination of biomarkers and transient elastography 
was concluded to be the most effective strategy to reveal significant fibrosis (29).

\section{Study Limitations}

The main limitation of the study is that the study was performed over male and considerable young population which could be considered as a selected population. Second, the results could be more valuable if we could have implemented non-invasive approaches, including serum bio-markers, scoring systems, and imaging techniques, for the assessment of liver fibrosis besides liver biopsy results. So, the results cannot be generalized to all patients, and there is a need for further prospective studies in generalized populations.

\section{Conclusion}

In summary, in our study group including young patients, all parameters except HAl showed a poorer diagnostic accuracy than biomarkers in literature like APRI, Fibrotest ${ }^{\circledR}$ or FIB-4 scores. Although age, AST, ALT and HAI revealed relatively better results than AST/ALT ratio and HCV-RNA for predicting $F \geq 3$ fibrosis, our results are not good enough to be relied on in the follow up process of $\mathrm{CHC}$. Including only young and male cases in the study could be considered as the limitation of the study, and more attention should be paid to adapting study results to the general population. Further randomized and controlled studies are needed in general population.

\section{Ethics}

Ethics Committee Approval: The study was approved by the Institutional Ethics Committee of on May 22th, 2017 (approval number: HNEAH-KAEK 2017/KK/71)

Informed Consent: Informed consent was obtained from the patients.

Peer-review: Externally peer-reviewed.

\section{Authorship Contributions}

Surgical and Medical Practices: E.Y., R.A.Ç., Concept: E.Y., Design: E.Y., R.A.Ç., Data Collection or Processing: E.Y., R.A.Ç., Analysis or Interpretation: E.Y., R.A.Ç., Literature Search: E.Y., R.A.C.., Writing: E.Y.

Conflict of Interest: The authors declare no conflict of interest.

Financial Disclosure: The authors declare that this study has not received any financial support.

\section{References}

1. Omata M, Kanda $T$, Wei $L$, Yu ML, Chuang $W L$, Ibrahim $A$ Lesmana CR, Sollano J, Kumar M, Jindal A, Sharma BC, Hamid SS, Dokmeci AK, Al-Mahtab M, McCaughan GW, Wasim J, Crawford DH, Kao JH, Yokosuka O, Lau GK1, Sarin SK. APASL consensus statements and recommendations for hepatitis $\mathrm{C}$ prevention, epidemiology, and laboratory testing. Hepatol Int. 2016;10:681-701

2. Pawlotsky JM, Negro $F$, Aghemo $A$, Berenguer $M$, Dalgard O, Dusheiko G, Marra F, Puoti M, Wedemeyer H. EASL recommendations on treatment of hepatitis C 2018. J Hepatol. 2018;69:461-511.

3. Tozun N, Ozdogan O, Cakaloglu Y, Idilman R, Karasu Z, Akarca U, Kaymakoglu S, Ergonul O. Seroprevalence of hepatitis B and C virus infections and risk factors in Turkey: a fieldwork TURHEP study. Clin Microbiol Infect. 2015;21:1020-1026.
4. Ghaderi-Zefrehi $H$, Gholami-Fesharaki $M$, Sharafi $H$, Sadeghi $F_{i}$ Alavian SM. The distribution of hepatitis $\mathrm{C}$ virus genotypes in Middle Eastern countries: a systematic review and meta-analysis. Hepat. Mon. 2016;16:e40357.5.

5. Ishak K, Baptista A, Bianchi L, Callea F, De Groote J, Gudat F, Denk $\mathrm{H}$, Desmet V, Korb G, MacSween RN, et al. Histological grading and staging of chronic hepatitis. J Hepatol. 1995;22:696-699.

6. Bruden DJ, McMahon BJ, Townshend-Bulson L, Gounder $P$ Gove J, Plotnik J, Homan C, Hewitt A, Barbour Y, Spradling PR, Simons BC, McArdle S, Bruce M. Risk of end-stage liver disease, hepatocellular carcinoma, and liver-related death by fibrosis stage in the hepatitis C Alaska Cohort. Hepatology. 2017;66:37-45

7. Degos F, Perez P, Roche B, Mahmoudi A, Asselineau J, Voitot $\mathrm{H}$, Bedossa P; FIBROSTIC study group. Diagnostic accuracy of FibroScan and comparison to liver fibrosis biomarkers in chronic viral hepatitis: a multicenter prospective study (the FIBROSTIC study). J Hepatol. 2010;53:1013-1021.

8. Shiha G, Ibrahim A, Helmy A, Sarin SK, Omata M, Kumar A Bernstien D, Maruyama H, Saraswat V, Chawla Y, Hamid S, Abbas Z, Bedossa P, Sakhuja P, Elmahatab M, Lim SG, Lesmana L, Sollano J, Jia JD, Abbas B, Omar A, Sharma B, Payawal D, Abdallah A, Serwah A, Hamed A, Elsayed A, AbdelMaqsod A, Hassanein T, Ihab A, GHaziuan H, Zein N, Kumar M.Asian-pacific association for the study of the liver (APASL) consensus guidelines on invasive and non-invasive assessment of hepatic fibrosis: a 2016 update. Hepatol Int. 2017;11:1-30.

9. AASLD/IDSA HCV Guidance Panel. Hepatitis C guidance: AASLDIDSA recommendations for testing, managing, and treating adults infected with hepatitis C virus. Hepatology. 2015;62:932-954.

10. Wu YJ, Xu MY, Lu LG. Clinical advances in fibrosis progression of chronic hepatitis B and C. J Clin Transl Hepatol. 2014;2:222227.

11. Sanai FM, Benmousa A, Al-Hussaini H, Ashraf S, Alhafi O, Abdo AA, Alameri HF, Akbar HO, Bzeizi KI. Is serum alanine transaminase level a reliable marker of histological disease in chronic hepatitis C infection? Liver Int. 2008;28:1011-1018.

12. Zeremski M, Dimova RB, Pillardy J, de Jong YP, Jacobson IM, Talal $\mathrm{AH}$. Fibrosis progression in patients with chronic hepatitis $\mathrm{C}$ virus infection. J Infect Dis. 2016;214:1164-1170.

13. Shahid M, Idrees M, Nasir B, Raja AJ, Raza SM, Amin I, Rasul A, Tayyab GU. Correlation of biochemical markers and HCV RNA titers with fibrosis stages and grades in chronic HCV-3a patients. Eur J Gastroenterol \& Hepatol. 2014;26:788-794.

14. Giannini E, Testa R. Is aspartate aminotransferase enough? Am J Gastroenterol. 2000;95:3687-3688.

15. Gupta RK, Sakhuja P, Majumdar K, Ali S, Srivastava S, Sachdeva S, Sharma BC, Puri AS. Incidentally detected asymptomatic hepatitis $C$ virus infection with significant fibrosis: Possible impacts on management. Indian Journal of Pathology \& Microbiology. 2018;61:345-349.

16. Khattab H, Fouad A, Hamza M, Mohey MA, El-Akel W, Ghoneim $\mathrm{H}$, Abul-Fotouh A, Esmat G. Relation of ALT and AST levels to the histopathological changes in liver biopsies of patients with chronic hepatitis C genotype 4. Arab J Gastroenterol. 2015;16:50-53.

17. Fecury AA, Almeida MK, Santos KN, Freitas Ada S, Dantas Sde F, Costa CA, Crescente ÂB, Sousa RC, Brito EB, Nassiri R, Lampe $\mathrm{E}$, Martins LC.Association between histological findings, aminotransferase levels and viral genotype in chronic hepatitis C infection. Rev Soc Bras Med Trop. 2014;47:90-92.

18. Zechini B, Pasquazzi C, Aceti A. Correlation of serum aminotransferases with HCV RNA levels and histological findings in patients with chronic hepatitis $\mathrm{C}$ : the role of serum aspartate transaminase in the evaluation of disease progression. Eur $\mathrm{J}$ Gastroenterol Hepatol. 2004;16:891-896.

19. Prati D, Taioli E, Zanella A, Della Torre E, Butelli S, Del Vecchio E, Vianello L, Zanuso F, Mozzi F, Milani S, Conte D, Colombo M, 
Sirchia G. Updated definitions of healthy ranges for serum alanine aminotransferase levels. Ann Intern Med. 2002;137:1-10.

20. Ruhl CE, Everhart JE. Upper limits of normal for alanine aminotransferase activity in the United States population. Hepatology. 2012;55:447-454.

21. Park HN, Sinn DH, Gwak GY, Kim JE, Rhee SY, Eo SJ, Kim YJ, Choi MS, Lee JH, Koh KC, Paik SW, Yoo BC. Upper normal threshold of serum alanine aminotransferase in identifying individuals at risk for chronic liver disease. Liver Int. 2012;32:937-944.

22. Pacifico L, Ferraro F, Bonci E, Anania C, Romaggioli S, Chiesa C Upper limit of normal for alanine aminotransferase: quo vadis? Clin Chim Acta. 2013;422:29-39.

23. Lai M, Hyatt BJ, Nasser I, Curry M, Afdhal NH. The clinical significance of persistently normal ALT in chronic hepatitis B infection. J Hepatol. 2007;47:760-767.

24. El-Sayed R, Fahmy M, El Koofy N, El-Raziky M, El-Hawary M, Helmy H, El-Akel W, El-Hennawy A, El-Karaksy H. Can aspartate aminotransferase to platelet ratio index replace liver biopsy in chronic hepatitis C? Trop Gastroenterol. 2011;32:267-272.
25. Mir IA. 21. Validity of serum markers for fibrosis staging in chronic hepatitis B and C. Journal of Clinical and Experimental Hepatology. 2018;8:23.

26. Sheth SG, Flamm SL, Gordon FD, Chopra S. AST/ALT ratio predicts cirrhosis in patients with chronic hepatitis $\mathrm{C}$ virus infection. Am J Gastroenterol. 1998;93:44-48

27. Park GJ, Lin BP, Ngu MC, Jones DB, Katelaris PH. Aspartate aminotransferase: alanine aminotransferase ratio in chronic hepatitis C infection: is it a useful predictor of cirrhosis? J gastroenterol Hepatol. 2000;15:386-390.

28. Li J, Gordon SC, Rupp LB, Zhang T, Boscarino JA, Vijayadeva V, Schmidt MA, Lu M; Chronic Hepatitis Cohort Study (CHeCS) Investigators. The validity of serum markers for fibrosis staging in chronic hepatitis B and C. J Viral Hepat. 2014;21:930-937.

29. Castera L, Bedossa P. How to assess liver fibrosis in chronic hepatitis C: serum markers or transient elastography vs. liver biopsy? Liver Int. 2011;31:13-17. 